\title{
The Crisis of Social Reproduction in Resettlement Colonies: A Case Study in Peri-Urban Chennai
}

\author{
Gajendran V. \\ Department of Humanities and Social Sciences, Indian Institute of Technology Madras, \\ Chennai
}

gajendranhssiitm@gmail.com

\begin{abstract}
Chennai, India's fourth largest metropolis is globalizing that includes urban renewal in the centre and large Special Economic Zones in the periphery. The latter is also the site of resettlement colonies of evicted people. Resettlement, as a consequence of government pursuing rapid economic growth via urban renewal, has multi-dimensional impacts. One of the main impacts is on their livelihoods. They depend on the opportunities in the places of their prior social and economic networks; from the places where they were evicted. This dependence also influences the return movement of people from the resettlement colony. On the other hand, as the city expands its urbanized territory, I explore if resettlement colonies can become spaces of opportunities for the people who are unable to pay higher housing rents in the city or series of small trades or for new migrants in search of jobs. This paper examines the livelihood issues of a resettlement colony in peri-urban Chennai. Fieldwork has been conducted in Chemmencherry, a resettlement colony. The case study method is used, as this method helps to capture the ground reality and micro processes at work. This study shows mixed results. The resettlement colony provides opportunities for certain groups of people and creates negative consequences for some other groups. Poverty is, however conspicuous among those forcefully resettled as well as among people who voluntarily migrated in to resettlement colony. This clearly shows that policy introduces a spatial characterization of poverty pushing it away from central city areas to the peri-urban with differential impacts on various groups. The social reproduction in resettlement areas is under crisis and there is an urgent need to develop policies and to explore political processes which helps the resettled people to overcome from this crisis.
\end{abstract}

\section{Introduction}

Chennai, one of the metropolises in India, is globalizing with urban renewal in its centre and industrialization in its peri-urban areas. Peri-urban areas are also sites of resettlement. The slum dwellers and the people who are affected by natural calamities are resettled in peri-urban areas. The resettlement of people due to natural calamities was due to Tsunami in 2004 and thereafter no such calamities and associated resettlement. However, the eviction of slum dwellers and resettling in peri-urban areas are continuing till today. According to Raman (2011), the slum rehabilitation program underwent a radical shift after the entry of World Bank funding. Prior to the entry of the World Bank, the slum rehabilitation program revolved around in situ housing programs and after the entry, precisely after 2000 , the policies are directed towards the resettlement of slum dwellers in the outskirts of Chennai.

For a long period of time the discussion on resettlement revolved around monetary compensation and provision of housing. According to the Asian Development Bank (2006), monetary compensation provided to the affected population was inadequate. Adequate compensation was suggested by researchers and over a period of time providing houses to displaced people received attention. However, the effectiveness of housing scheme for displaced people is not under the scrutiny of academic researchers. Though houses were provided to the evicted population in resettlement colonies people tend to leave resettlement sites. According to Asif (2000), people, mainly tribal people, reject resettlement offers in order to escape from the surveillance of state. He argues that 
the people who are not under the surveillance of state are brought under surveillance through resettlement programs and people who are subjected to resettlement rejects the resettlement program in order to escape from surveillance. While Asif explains the outward movement of population in rural tribal context, this paper tries to understand the return movement of population from the resettlement colonies in an urban context. It also tries to understand the reasons for the inward movement of population into resettlement colonies and it also throws light on the crisis of social reproduction among the people who lives in Chemmencherry.

In this context, this paper tries to understand the effectiveness of slum dwellers resettlement programs in the peri-urban areas and tries to understand the consequences associated with resettlement. The fieldwork for this research is conducted in Chemmencherry a resettlement colony in peri-urban areas of Chennai. The first part explains the methodology used in this research and the second section elaborated the findings of this research, mainly deals with employment opportunities of the people in the resettlement colonies, the return and inward movement of population and the issues of people who suffer from the high housing rents in the central part of the city and followed by a conclusion.

\section{Methodology}

The fieldwork for this research is conducted in Chemmencherry, a resettlement colony in a peri-urban area. The objectives are: 1) to understand the relationship between resettlement program through which people in the central part of the city are forcefully resettled in Peri-urban areas and the crisis, they face 2) to find out the reasons for the return to the city and inward movement of population into resettlement colonies. Case study method is used in this research. About fifty people in the resettlement colonies were interviewed through semi-structured questions, including key informants, forcefully resettled people, people who voluntarily moved in to resettlement colony and people who moved out from resettlement colony and lives in the places where they were displaced. Purposive sampling method is used to identify the samples. The interviews were recorded and transcribed. In order to help the reader to understand the issues of resettlement shorter version of case studies are given in the main text as examples.

\section{Results and Discussion}

\section{A) Livelihood Issues of Resettled Population}

The resettlement of people from the central part of the city to Chemmencherry is justified by the statement that highlights the merit of its Information Technology (IT) Corridor. The employment opportunities in IT Companies and construction projects in the nearby areas created an assumption that resettled population will not suffer from unemployment. However, ground realities show that resettled population suffered from unemployment and nonavailability of jobs with social security. Most of the residents are unorganized workers ${ }^{1}$. Men are involved in construction work, security service jobs, auto driving and etc and most of the women are paid domestic worker and a few works as security guards and office staffs.

Even though most of the men are construction workers they unable to find jobs in construction projects in nearby places, because those projects are carried out by big construction companies and they prefer cheap migrant labourers. According to Karuppaih ${ }^{2}$, a construction worker living in Chemmencherry, Most of the big projects in the nearby areas are undertaken by big construction companies and those companies prefer people who from Andhra, Orissa and Hindi speaking areas. Big construction companies do not prefer Tamil people because they demand wages which is more than 500 rupees, however, people from Andhra, Orissa and other places work for 500 rupees per day. This clearly shows that employment opportunities in the construction projects in the nearby areas are taken away by migrant workers from the resettled population. Moreover, there are possibilities for undertaking contracts related to construction work such as interior decoration mainly painting work, and security services.

\footnotetext{
${ }^{1}$ In India, the word unorganized workers is widely used instead of Informal workers.

${ }^{2}$ Interview dated: 4th June 2014.
} 
However, those opportunities are limited and not feasible for resettled people because of the requirements demanded by construction companies and IT Companies. Mainly the painting orders are given to registered companies through tender process. The registration of a company even at small scale requires economic capital as well as state approval, which results in excluding the resettled population from tender process even though they have experience in the field and those opportunities are taken away by registered companies. For example, Ramesh is a professional painter and he has forty years experience in the painting work. He learned painting work from his childhood. However, he was unable to get contracts related to painting work from IT companies and construction projects, because most of the painting work is given to registered companies. He was unable to register a company at small scale, due to financial constraints and now he works as a security guard for salary of eight thousand rupees which is inadequate to run his family. The security services were also given to registered security agencies.

Due to non-availability of work in nearby places, resettled population in Chemmencherry uses their prior social networks in the places where they were displaced. Mainly women use prior social networks to get employment in paid domestic work. For example, Karuppiah is a Masthiri. His work is to organize labour for construction work. He moved to Chemmencherry with his family in 2006 under Tsunami Scheme. After moving to Chemmencherry his wife began to work as paid domestic worker. His wife goes to Pattinapakkam every day to do the work. Pattinapakkam is the place, where Karuppia's family lived before resettlement. His wife goes to Pattinapakkam because she was unable to find work in nearby places. According to Karuppiah, there are many apartments in nearby areas, but his wife was unable to find work because the residents of those apartments employ the women from the places where residents lived earlier. Therefore his wife goes to Pattinapakkam for work ${ }^{4}$.

\footnotetext{
${ }^{3}$ Interview Dated: 25 May 2014

${ }^{4}$ Interview Dated: 04 June 2014
}

However, travelling to city consume more time and money. The long travelling time and money spent for travel created a burden on resettled population. Those who are unable to manage the burden of long travelling time and travel expenses tend to work as subcontractors, for instance, Philip Kumar, a forty seven years old man, is involved in work related to interior decoration. He was unable to get interior contracts in IT companies and construction projects in nearby areas and those contracts were given to big companies involved in interior decoration. However, he has taken sub-contracts from the big contractors who have undertaken interior decoration contracts ${ }^{5}$ or employees under contractors who have taken construction work related contracts and security service contracts under the highly exploitative situation, for example, Lakshamanan moved to Chemmencherry and joined in a private security service Company. He obtained that job because his Scout experience during his school days. However, the job was highly exploitative; he has to work for 12 hours per shift and moreover, they forced him to do two shifts continuously, which means he has to work for 24 hours continuously. Moreover, he was not allowed to leave after doing two shifts since his regular shift begins after the second shift; as a result he worked for 36 hours continuously in between he sleeps for two, three hours my making understanding with the fellow security guards and the fellows also do like him. On the other hand, he received only 9000 rupees as salary and he will get 8000 rupees at hand after detection of ESI and PF, but security companies get more money from the companies ${ }^{6}$. Those who do not want to work under such exploitative situation, move out from resettlement colony and lives in the central part of the city where they have easy access to employment and social networks. For example, Veera Kumar received a house in Chemmencherry through slum clearance program. He was unable to earn money like he earned in Chennai. He lived in Chemmencherry for a year and then he resettled himself in the city where he has access to employment and prior social networks related to his employment ${ }^{7}$.

\footnotetext{
${ }^{5}$ Interview Dated: 13 June 2014

${ }^{6}$ Interview Dated: 10 May 2014.

${ }^{7}$ Interview Dated: 28 July 2015.
} 
In short, resettled people were excluded from employment in the nearby areas which made them work in city which consumes time and money, those who are unable to face the burden of travailing time and expenditure on travel either work in a highly exploitative situation under contractors or they move back to the city.

\section{B) The Return and Inward Movement of Population}

The crisis in employment paved way for the outward movement of people from Chemmencherry. This in turn resulted in formation of informal rental housing market in the Chemmencherry resettlement colony. The rental housing market operates in an informal way because renting a house by the person who has allotment to another person is illegal in the view of the state. According to the sate the house should be used by the allottee. Moreover, allottee does not have the title deed of the house, and allottee will get the title deed only after the payment of sixty thousand rupees in installments. The installment amount per month is 250 rupees and the person who has allotment have to pay 250 rupees for 20 years and after twenty years the person will get the title deed. Hence the paradox is the person who rent the house is paying rent the state. In contrast, the people who received an allotment of the house through Tsunami Rehabilitation program need not to pay rent to slum clearance program and they have to pay 50 rupees as maintenance Charges. However, allottee of Tsunami House Scheme cannot transfer the ownership of the house to other persons. In case, allottee of Tsunami house dies the ownership can be transferred to one of the family members, mainly wife/husband of the person whom died. This clearly shows that official transaction such as sale and renting of houses by allottee to other persons is strictly prohibited, which in turn resulted in informal transactions.

Even though renting a house is illegal in the view of the state, allottee those who move out from Chemmencherry do not want their houses to be vacant and they rent their houses through informal means. The people who are unable to pay the high house rents in the city used this opportunity and moved into the resettlement colony in order to escape from the burden of high rent in the city. For example, Saravanan ${ }^{8}$, fifty four years old men, moved to Chemmencherry in 2006 from Triplicane, which is located nearer to Marina Beach. He lives in one of his friend's house by paying rent and his friend received the house from Slum Clearance Board of Tamil Nadu. Saravanan earns 400 rupees per day, i.e. 12000 rupees per month. According to him if he lives in the city he has to spend at least 6000 rupees for housing rent, which is fifty percent of his earnings. Now, he is paying 1500 rupees per month as rent which is $13 \%$ of his income. ${ }^{9}$ Moreover, because of low housing rent, it is easier for the people to rent a house who migrate from other places to Chennai in search of jobs. For instance the statement of a Muslim migrant woman follows, "In order to get a job I migrated along with my husband from Nagapatianam district to Chennai. We faced hardship in finding jobs in our hometown and there was restriction for me to take jobs in rural setting. However, in Chennai I have the freedom to work. We came to Chemmencherry before one and a half years. My husband had some contact in Chemmencherry and through that contact we took a house for rent and the rent is affordable for us" ${ }^{\prime \prime}$. A key informant in Chemmencherry reported that a few of migrants from northern parts of India hire houses for rent, because of low housing rent. On the other hand, the housing rent obtained by allottee from their houses in Chemmencherry is used to reduce the burden of house rent in the city.

In short, resettlement has resulted in crisis on employment which in turn resulted in an outward movement of people from the resettlement colony. This situation created an opportunity for the people who suffer from the burden of high housing rent in the city they used this opportunity and moved into Chemmencherry.

\section{C) The Crisis of Social Reproduction}

Although Chemmencherry provides opportunity for certain groups of people and

\footnotetext{
${ }^{8}$ Name Changed.

${ }^{9}$ Interview Dated: 10 May 2014

${ }^{10}$ Interview Dated: $10^{\text {th }}$ May 2014.
} 
negative consequences for some other groups and which also resulted in inward and outward movement of population, the groups which the groups moved in and out are poorer groups and hence the resettlement colony characterizes the spatial concentration of poverty. Poverty is visible among all groups of people and resulted in crisis of social reproduction. The crisis of social reproduction can be captured through the physical and social environment.

The physical environment mentioned here is related to the size of the houses in Chemmencherry. The size of the houses in Chemmencherry is not adequate for good living conditions. According to Lakshmanan ${ }^{11}$, a resident of Chemmencherry Colony, at least 500 square feet sized house is necessary for a decent living. However, the size of the house in Chemmencherry is 220 square feet, including toilet and the walls of a house and the actual living space is 185 square feet including kitchen. A small portion of the 185 square feet is separated by a wall from Kitchen and the rest of the space is used as both bedroom as well as hall. Despite the size of the house the number of people sharing the room is alarming, because in most of the houses about four to seven members of a family share the small space. For example, Parveen lives in Chemmencherry and she is a paid domestic worker. She has five daughters. The number of family members is seven, including her husband and all the seven members' shares the 220 square feet sized house $^{12}$. The social environment here is relates to social networks. Social networks play an important role in getting employment. A mixed response is received in this research related to prior social networks, some of the respondents say that they have lost the prior social networks related to employment, for example, Ravichandran was a construction worker. He lost his house due to Tsunami and he received a house in Chemmencherry through Tsunami Housing Scheme and he moved to Chemmencherry in 2006. After moving to Chemmencherry, he was unable to maintain his social networks related to construction work in the place from where he was displaced. He lost that network due to

\footnotetext{
${ }^{11}$ Interview Dated: $10^{\text {th }}$ May 2014.

${ }^{12}$ Interview Dated: 10 May 2014.
}

long travelling time. Therefore, he left construction work and turned into an auto rickshaw driver ${ }^{13}$ and some of the respondents say that they used their prior social networks to get employment, for example, Alamelu, sixty years old women, resettled in Chemmencherry from Besant Nagar. She was unable to get employment in the nearby places and therefore she used her social network in Besant Nagar to get employment in paid domestic work. Every day she travels to Besant Nagar in the morning and return in the afternoon ${ }^{14}$ and a few other respondents say that they got employment through neighbours in the resettlement colony. However, various groups in Chemmencherry are able to get employment in unorganized sector, mainly construction work in the case of men and paid domestic work in case of women through their social networks. Since their social networks are weak, they are unable to move upward in economic status and remain poor.

The lack of opportunities for upward mobility in economic and social status had a great impact on the future of people living in Chemmencherry. Most of the people who forcefully resettled and voluntarily migrated into Chemmencherry are unable to envision their future. For example, Rameshwari lives with her mother in Chemmencherry along with her daughter. She left her husband due to misunderstanding and her husband is in Andhra Pradesh. She is working with printing press. She gets eight thousand rupees as salary. When the researcher asked about her future plan she immediately replied that she does not have any future plan and her statement follows: "Nothing is in my hand, I get money to run my family if and only if I work. If I sit in my house for a month I cannot run my family and how can I think about future plan and I am not in situation to think about my future plan"15. People in Chemmencherry were also very much worried about the future of their children. To sum up, both the physical and social environments in Chemmencherry are very much responsible for the crisis of social reproduction. Upward mobility in the economic and social status is almost not possible for the people living in

\footnotetext{
${ }^{13}$ Interview Dated: 10 May 2014.

${ }^{14}$ Interview Dated: 13 June 2014.

${ }^{15}$ Interview Dated: 22 June 2014.
} 
Chemmencherry and this situation push them into a chaotic situation and the end result is blurred future.

\section{Conclusion}

Merely providing house cannot be a proper resettlement. The case studies in Chemmencherry clearly show that the resettlement project, which forcefully displace and resettle people in peri-urban areas, is not an appropriate solution for housing the slum dwellers and people who are affected by natural calamities. Due to lack of employment opportunities the return movement of population is unavoidable. Resettlement without employment opportunities will end up in the return movement of population as well as crisis of social reproduction in resettlement colonies. Therefore, policies should focus on providing adequate sized housing and employment opportunities for the welfare of resettled people. Since most of the resettled people in Chemmencherry are unorganized worker policies which promote "Home Based Enterprises (HBEs)" will be very much useful.
According to Tipple (2005), HBEs plays an important role in employment generation and the alleviation of poverty although income generated through HBEs is low. Therefore including HBEs in resettlement plan will be helpful in generating employment. On the other hand, there is an urgent need to address the issue of rental housing in the city. The high housing rents in the city have a negative impact on people who lives in rented houses, they tend to move towards periphery of the city and hence the policies which aims to address the issues of the poor should focus on developing a rental housing scheme in periurban areas which helps people to move out from the city and resettle themselves in periurban areas in a voluntary manner. In mean time, allowing allottees to rent their houses in resettlement colonies to people who seek rental housing can be beneficial for both the parties and hence legalization of rental housing market should be considered in policy making process.

\section{REFERENCES}

Asian Development Bank (2008), Asian Development Bank's Involuntary Resettlement Safeguards Project Case Studies in India, Operation Evaluation Department, Asian Development Bank. Available from: http://www.oecd.org/derec/adb/47108353.pdf. [Accessed: 20th July 2015].

Asif, Mohammed (2000), Why Displaced Persons Reject Project Resettlement Colonies, Economic \& Political Weekly, 35 (24). P. 2005-2008.

Raman, Nitya, (2011) The Board and the Bank: Changing Policies towards Slums in Chennai, Economic \& Political Weekly, 46 (31). P.74-80.

Tipple, Graham (2005), The Place of Home-based Enterprises in the Informal Sector: Evidence from Cochabamba, New Delhi, Surabaya and Pretoria, Urban Studies, 42 (4). P.611-632. 